\title{
Modulating nuclear receptor function: may the phos be with you
}

\begin{abstract}
Dalei Shao and Mitchell A. Lazar
Division of Endocrinology, Diabetes, and Metabolism, Departments of Medicine and Genetics and The Penn Diabetes Center, University of Pennsylvania School of Medicine, Philadelphia, Pennsylvania 19104-6149, USA

Address correspondence to: Mitchell A. Lazar, University of Pennsylvania School of Medicine, 611 CRB, 415 Curie Boulevard, Philadelphia, Pennsylvania 19104-6149, USA. Phone: (215) 898-0210; Fax: (215) 898-5408; E-mail: lazar@mail.med.upenn.edu.
\end{abstract}

Gene expression is tightly regulated in response to both extracellular and intracellular signals, which control virtually every biological process. Intracellular signaling molecules such as steroid hormone, thyroid hormone, retinoids, and vitamin $\mathrm{D}$ exert their function through direct binding to their cognate nuclear receptors (1). Nuclear receptors are transcription factors that recognize specific sequences in target genes via a centrally located DNA-binding domain (DBD). Some receptors bind DNA as monomers, some as homodimers, and some as heterodimers with a common partner, the retinoid $\mathrm{X}$ receptor (RXR). Both the DBD and the COOHterminal ligand-binding domain (LBD) contribute to dimerization. Many nuclear receptors repress transcription in the absence of ligand, due to a repression function in the LBD. Interaction of the LBD with ligand abolishes repression and activates transcription via a $\mathrm{COOH}$-terminal activation domain (activation function 2, or AF2), which in some receptors works in tandem with an additional activation domain (AF1) in the $\mathrm{NH} 2$-terminus, or A/B region. There are over 150 mammalian members of the nuclear receptor superfamily. Many of these are "orphan" receptors, whose ligands are yet to be discovered.

In contrast to the small lipophilic molecules that signal via nuclear receptors, extracellular signaling molecules such as peptide hormones and cytokines communicate with their intracellular targets through surface receptors, which activate signal transduction pathways that ultimately lead to regulation of gene expression mediated by transcription factors such as fos, jun, cAMP-response element binding protein (CREB), and others. Most often the mechanism involves direct phosphorylation of the transcription factor by a kinase that is activated as a result of the ligand-receptor interaction at the cell surface. Nuclear receptors are also targets of kinases involved in signal transduction.

In this issue of the JCI, Kremer and colleagues report that activation of mitogen-activated protein kinase (MAPK) attenuates the ligand-dependent transactivation function of the vitamin $\mathrm{D}$ receptor (VDR) and its heterodimer partner RXR (2). This effect appears to be mediated by phosphorylation of human RXR $\alpha$ on a serine residue at amino acid 260 in the protein. This report not only provides a potential mechanism for ras-induced transformation of human keratinocytes, but also has broader implications because RXR heterodimerizes with several other nuclear receptors including thyroid hormone receptor, retinoic acid receptor, and peroxisome proliferator-activated receptor. Thus, it will be interesting to determine in future studies whether phosphorylation of RXR alters the biological activity of these receptors.

Phosphorylation of nuclear receptors provides an important mechanism for crosstalk between signaling pathways. Phosphorylation has been shown to modulate the activity of many nuclear receptors (Table 1). Multiple kinase pathways have been implicated, including cAMP-dependent protein kinase, casein kinase, glycogen synthase kinase (GSK), jun kinase, cyclin-dependent kinases (Cdks), and MAPKs. All aspects of receptor function can be regulated, including DNA binding and dimerization, transcriptional activity, interaction with cofactors, and ligand-binding affinity.

The mechanism by which phospho- rylation of RXR inhibits vitamin D signaling is not clear. Phosphorylated RXR was not recognized by an antibody that recognized the nonphosphorylated protein, suggesting that phosphorylation resulted in a conformational change in the protein. Such a change in tertiary structure might alter affinity of the VDR/RXR heterodimer for transcriptional coregulators. This is an attractive hypothesis because ligand activation of nuclear receptors is clearly related to a conformational change that favors coactivator interaction (3). An alternative possibility is that the phosphate group has a more direct role in a critical function such as coregulator interaction, as has been observed for the interaction between phosphorylated CREB and its main coactivator CBP (4). Although the structures of the DBD and LBD have been solved for numerous receptors, no full-length receptor has been crystallized, nor has the structure of any phosphorylated nuclear receptor been determined. Thus, it remains to be determined which effects of phosphorylation listed in Table 1 are due to conformational changes and which are due to more localized effects of the phosphate group on receptor function. Moreover, the combination of phosphorylation and ligand binding may in some cases lead to an entirely novel structure.

The concept that nuclear hormone receptor function is determined by rapid, reversible, and combinatorial structural changes governing interactions with other cellular proteins provides a framework for understanding how the receptor can integrate a variety of signals in a physiological context. This level of understanding puts us light years ahead of where we were just a short time ago. 
Table 1

Phosphorylation of nuclear receptors

\begin{tabular}{|c|c|c|c|c|}
\hline Receptor & Kinase & Site(s) & Effect of phosphorylation & Reference \\
\hline AR & PKA & Ser641, 653 & Promote ligand-dependent and ligand-independent activation & 5 \\
\hline ER & $\begin{array}{l}\text { PKA, } \\
\text { MAPK } \\
\text { MAPK } \\
\text { Receptor tyrosine kinases }\end{array}$ & $\begin{array}{l}\text { Ser236 (ER } \alpha) \\
\text { Ser118 (ER } \alpha) \\
\text { Ser106,124(ER } \beta) \\
\text { Tyr537(ER } \alpha)\end{array}$ & $\begin{array}{l}\text { Inhibit dimerization and DNA binding } \\
\text { Promote ligand-dependent and ligand-independent activation } \\
\text { Promote ligand-dependent and ligand-independent activation } \\
\text { Enhance ER interaction with SRC-1 }\end{array}$ & $\begin{array}{l}6 \\
7 \\
8 \\
9\end{array}$ \\
\hline GR & $\begin{array}{l}\text { MAPK } \\
\text { CDKs } \\
\text { GSK-3 }\end{array}$ & $\begin{array}{l}\text { Ser246 } \\
\text { Ser224, } 232 \\
\text { Thr171 }\end{array}$ & $\begin{array}{l}\text { Inhibit ligand-dependent activation } \\
\text { Enhance ligand-dependent activation } \\
\text { Inhibit ligand-dependent activation }\end{array}$ & $\begin{array}{l}10 \\
10 \\
11\end{array}$ \\
\hline PR & $\begin{array}{l}\text { CDK2 } \\
\text { Casein kinase }\end{array}$ & $\begin{array}{l}\text { Ser } 162,190,400 \\
\text { Ser102, 294, } 345\end{array}$ & $\begin{array}{l}\text { Ligand-independent activation } \\
\text { Regulate hormone-dependent activation }\end{array}$ & $\begin{array}{l}12 \\
13\end{array}$ \\
\hline \multirow[t]{2}{*}{ TR } & $\begin{array}{l}\text { Casein kinase } \\
\text { PKA } \\
\text { PKA }\end{array}$ & $\begin{array}{l}\text { Ser474,475 (TR } \alpha 2) \\
\text { Ser28/29(TR } 1) \\
\text { Ser16/17(v-erb A) }\end{array}$ & $\begin{array}{l}\text { Inhibit monomer DNA binding } \\
\text { Inhibit monomer DNA binding } \\
\text { Inhibit monomer DNA binding }\end{array}$ & $\begin{array}{l}14 \\
15 \\
16\end{array}$ \\
\hline & & Multiple sites (TR $\beta)$ & $\begin{array}{l}\text { Tissue-specific stabilization } \\
\text { Promote RXR heterodimerization }\end{array}$ & $\begin{array}{l}17 \\
18\end{array}$ \\
\hline RAR & $\begin{array}{l}\text { Cdk7/TFIIH } \\
\text { PKA }\end{array}$ & $\begin{array}{l}\text { Ser77 (RAR } \alpha 1) \\
\text { Multiple sites }\end{array}$ & $\begin{array}{l}\text { Increase AF1 transactivation } \\
\text { RA-dependent activation }\end{array}$ & $\begin{array}{l}19 \\
20\end{array}$ \\
\hline$R \times R$ & $\begin{array}{l}\text { MAPK } \\
\text { PKA }\end{array}$ & $\begin{array}{l}\text { Ser } 260 \\
\text { Multiple sites }\end{array}$ & $\begin{array}{l}\text { Inhibit RXR and VDR ligand-dependent activation } \\
\text { RA-dependent activation in muscle cells }\end{array}$ & $\begin{array}{l}2 \\
21\end{array}$ \\
\hline PPAR $\gamma$ & $\begin{array}{l}\text { MAPK } \\
\text { JNK/SAPK }\end{array}$ & $\begin{array}{l}\text { Ser112 (PPAR } 2 \text { ) } \\
\text { Ser82 (PPAR } \gamma 1)\end{array}$ & $\begin{array}{l}\text { Decrease ligand-independent activation } \\
\text { Decrease ligand-binding affinity } \\
\text { Decrease ligand-dependent activation }\end{array}$ & $\begin{array}{l}22 \\
23 \\
24\end{array}$ \\
\hline PPAR $\alpha$ & Insulin-activated kinase & Not known & Increase ligand-dependent activation & 25 \\
\hline SF-1 & MAPK & Ser203 & Promote cofactor recruitment of LBD & 26 \\
\hline HNF4 & PKA & Multiple sites & Promote DNA binding & 27 \\
\hline Nurr77 & PP90rsk & Ser354 & Inhibit DNA binding & 28 \\
\hline
\end{tabular}

This table is intended to illustrate the range of receptors, kinases, and regulated functions. We regret that because of space limitation, not all examples could be cited.

\section{Acknowledgments}

We thank the National Institute for Diabetes Digestive and Kidney Diseases (NIDDK) for grants in support of research in the lab of M.A. Lazar.

1. Mangelsdorf, D.J., et al. 1995. The nuclear receptor superfamily: the second decade. Cell. 83:835-839.

2. Solomon, C., White, J.H., and Kremer, R. 1999. MAP kinase inhibits 1,25-dihydroxyvitamin D3dependent signal transduction by phosphorylation of human $\mathrm{RXR} \alpha$ on serine 260. J. Clin. Invest. 103:1729-1735.

3. Nolte, R.T., et al. 1998. Ligand binding and coactivator assembly of the peroxisome proliferator-activated receptor- $\gamma$. Nature. 395:137-143.

4. Radhakrishnan, I., et al. 1997. Solution structure of the KIX domain of CBP bound to the transactivation domain of CREB: a model for activator:coactivator interactions. Cell. 91:741-752.

5. Nazareth, L.V., and Weigel, N.L. 1996. Activation of the human androgen receptor through a protein kinase A signaling pathway. J. Biol. Chem. 271:19900-19907.

6. Chen, D., Pace, P.E., Coombes, R.C., and Ali, S. 1999. Phosphorylation of human estrogen receptor alpha by protein kinase A regulates dimerization. Mol. Cell. Biol. 19:1002-1015.

7. Kato, S., Kitamoto, T., Masuhiro, Y., and Yanagisawa, J. 1998. Molecular mechanism of a crosstalk between estrogen and growth-factor signaling pathways. Oncology. 55(Suppl 1.):5-10.

8. Tremblay, A., Tremblay, G.B., Labrie, F., and Giguere, V. 1999. Ligand-independent recruitment of SRC-1 to estrogen receptor beta through phosphorylation of activation function AF-1. Mol. Cell. 3:513-519.

9. Auricchio, F., et al. 1996. Protein tyrosine phosphorylation and estradiol action. Ann. NY Acad. Sci. 784:149-172.

10. Krstic, M.D., Rogatsky, I., Yamamoto, K.R., and
Garabedian, M.J. 1997. Mitogen-activated and cyclin-dependent protein kinases selectively and differentially modulate transcriptional enhancement by the glucocorticoid receptor. Mol. Cell. Biol. 17:3947-3954.

11. Rogatsky, I., Waase, C.L., and Garabedian, M.J. 1998. Phosphorylation and inhibition of rat glucocorticoid receptor transcriptional activation by glycogen synthase kinase-3 (GSK-3). Speciesspecific differences between human and rat glucocorticoid receptor signaling as revealed through GSK-3 phosphorylation. J. Biol. Chem. 273:14315-14321.

12. Zhang, Y., et al. 1997. Phosphorylation of human progesterone receptor by cyclin-dependent kinase 2 on three sites that are authentic basal phosphorylation sites in vivo. Mol. Endocrinol. 11:823-832.

13. Zhang, Y., et al. 1994. Identification of phosphorylation sites unique to the $B$ form of human progesterone receptor. In vitro phosphorylation by casein kinase II. J. Biol. Chem. 269: 31034-31040.

14. Katz, D., Reginato, M.J., and Lazar, M.A. 1995. Functional regulation of thyroid hormone receptor variant TR alpha 2 by phosphorylation. Mol. Cell. Biol. 15:2341-2348.

15. Tzagarakis-Foster, C., and Privalsky, M.L. 1998. Phosphorylation of thyroid hormone receptors by protein kinase A regulates DNA recognition by specific inhibition of receptor monomer binding. J. Biol. Chem. 273:10926-10932.

16. Glineur, C., Zenke, M., Beug, H., and Ghysdael, J. 1990. Phosphorylation of the v-erbA protein is required for its function as an oncogene. Genes Dev. 4:1663-1676.

17. Ting, Y.T., Bhat, M.K., Wong, R., and Cheng, S. 1997. Tissue-specific stabilization of the thyroid hormone beta1 nuclear receptor by phosphorylation. J. Biol. Chem. 272:4129-4134.

18. Bhat, M.K., Ashizawa, K., and Cheng, S.Y. 1994. Phosphorylation enhances the target gene sequence-dependent dimerization of thyroid hormone receptor with retinoid $\mathrm{X}$ receptor. Proc.
Natl. Acad. Sci. USA. 91:7927-7931.

19. Rochette-Egly, C., et al. 1995. Phosphorylation of the retinoic acid receptor-alpha by protein kinase A. Mol. Endocrinol. 9:860-871.

20. Taneja, R., et al. 1997. Phosphorylation of activation functions AF- 1 and AF- 2 of RAR alpha and RAR gamma is indispensable for differentiation of F9 cells upon retinoic acid and cAMP treatment. EMBO J. 16:6452-6465.

21. Dowhan, D.H., and Muscat, G.E. 1996. Characterization of the $\mathrm{AB}(\mathrm{AF}-1)$ region in the musclespecific retinoid $X$ receptor-gamma: evidence that the AF-1 region functions in a cell-specific manner. Nucleic Acids Res. 24:264-271.

22. Adams, M., Reginato, M.J., Shao, D., Lazar, M.A., and Chatterjee, V.K. 1997. Transcriptional activation by peroxisome proliferator-activated receptor gamma is inhibited by phosphorylation at a consensus mitogen- activated protein kinase site. J. Biol. Chem. 272:5128-5132.

23. Shao, D., et al. 1998. Interdomain communication regulating ligand binding by PPAR-gamma. Nature. 396:377-380.

24. Camp, H.S., Tafuri, S.R., and Leff, T. 1999. c-Jun $\mathrm{N}$-terminal kinase phosphorylates peroxisome proliferator-activated receptor $\gamma 1$ and negatively regulates its transcriptional activity. Endocrinology. 140:392-397.

25. Shalev, A., et al. 1996. The peroxisome proliferator-activated receptor $\alpha$ is a phosphoprotein: regulation by insulin. Endocrinology. 137:4499-4502.

26. Hammer, G.D., et al. 1999. Phosphorylation of the nuclear receptor SF-1 modulates cofactor recruitment: integration of hormone signaling in reproduction and stress. Mol. Cell. 3:521-526.

27. Jiang, G., Nepomuceno, L., Yang, Q., and F.M Sladek. 1997. Serine/threonine phosphorylation of orphan receptor hepatocyte nuclear factor 4 . Arch. Biochem. Biophys. 340:1-9.

28. Davis, I.J., Hazel, T.G., Chen, R.H., Blenis, J., and Lau, L.F. 1993. Functional domains and phosphorylation of the orphan receptor Nur77. Mol. Endocrinol. 7:953-964. 